\title{
Exploring the Key Principles of Hamas Foreign Relations
}

\author{
PhD Candidate, Abdalhakim Hanaini
}

\author{
Dr. Abdul Rahim Bin Ahmad (Supervisor)
}

National University Malaysia (UKM); Abedqatar123@gmail.com

\section{Doi:10.5901/mjss.2016.v7n3s1p207}

\begin{abstract}
Hamas has established political relations with a number of countries and opened representation offices in some of them. This paper explores the principles that shaped the foreign relations policy of the movement. This research is qualitative in nature, utilizing the analytical-descriptive and historical methods. Semi-structured interviews with the most notable leaders of the movement were conducted; and a set of primary and secondary historical documents, specifically those present in the movement's archives were analyzed thoroughly. The findings have shown that Hamas is striving to accomplish the interests of the Palestinian people based on the 'Public Interest' principle. Politically, Hamas is also open to all countries, political parties and international organizations (excluding the occupying state of Israel) based on the premise that the interaction and cooperation are the essence of human relations.' Furthermore, Hamas constantly emphasises the independence of its decision-making, rejects dictations, does not interfere in the internal affairs of sovereign states, does not get involved into game of conflicting axes or clashes, and does not conduct armed operations outside of Palestine. To conclude, being committed to the above-mentioned principles, Hamas has been able to maintain positive relations with countries and parties.
\end{abstract}

Keywords: Hamas, Foreign Relations, Interests, Principles, Interaction

\section{Introduction}

The Islamic Resistance Movement 'also called Hamas, ( the Arabic acronym to Islamic Resistance movement, Harakat Moqawama Islameyah. It means also zeal and Enthusiasm, the author), is a Palestinian national liberation movement, emerged in 1987. Hamas is not a mere military movement, and it possesses its own political vision and objectives. It is a popular movement that shares the sorrows of the Palestinian people, both in Palestine and in Diaspora, defending their interests and dedicated to their service (K. Meshal, personal communication, April 19, 2015). It has been striving to liberate the Palestinian land from the oppressive Israeli occupation. Hamas has unequivocally stated that it is also an Islamic movement since its inception and emergence from the Muslim Brotherhood. Islam is the frame of reference for its ideology, worldview and understanding of man and life. In essence, Islam guides the behaviours of the movement in all (Hurub, 1996: 288). Even the movement's socio-political and military undertakings are furthermore based on Islamic principles. Hence, the Islamic Sharia's (law) provisions have remained greatly significant to the implementation of the movement's policies and positions (S. Khater, personal communication, March 25, 2015).

To achieve its objectives, Hamas has adopted both military and political approaches. Good examples of its political approaches - the prime focus of this paper- are Hamas participation in the Palestinian Legislative Council (PLC) in 2006, then formation the Palestinian government, and the establishment of official and unofficial foreign relations with various countries of the international community, including Turkey, Iran, Sudan, Jordan, Yemen, Malaysia and Egypt. Meanwhile, Hamas considers building foreign relations with all countries of the world-with the singular exception of the occupying state i.e., Israel-and international organizations as one of its prime means to accomplish its interim and strategic objectives. In this vein, Hamas has established and improved these relations on the basis of a number of principles. Some of these principles are found and derived from the Islamic Sharia, and Islamic Fiqh (jurisprudence); while others are derived from careful study and analysis of various former cases and experiences of other Palestinian liberation movements and factions, such as the factions under the Palestinian Liberation Organization (PLO). Therefore, this paper further explores the key principles that shaped the foreign relations policy of Hamas movement. More specifically, the first part of the current paper deals with the principles that stemmed from Islamic Sharia, while the other part investigates the principles stemmed from practical experiences.

\section{Research Method}

Overall, this particular research is qualitative in nature. This approach helps researchers to understand the issue being 
investigated in a more comprehensive way (Creswell, 2013). It utilized the analytical method to further examine and analyze the data collected form primary and secondary resources. The researcher browsed a number of primary resources available on the internet, mainly the official website of Hamas (www.hamas.info) as well as other internal documents available at Hamas leadership offices in Qatar and Turkey. Moreover, to get more in depth information about the principles of Hamas foreign relations, semi-structured interviews with Hamas political leaders among whom are , Khalid Meshal, the current leader of Hamas political bureau and the current and ex-head of the foreign relation department, Mohammad Swalha and Osama Hamdan respectively, and other members in the political bureau. These interviews were used because "the questions are flexibly worded to form a guide to the issues to be explored (Mariam, 2009, p.341). The interview data were analysed, and the ideas and themes were coded based on the research purpose (Creswell, 2013).

\section{Analysis and Discussion}

\subsection{Principles stemmed from Islamic Sharia}

\subsubsection{Principle of masaleh mursala (public interest)}

Hamas movement has relied on the Islamic Sharia provision, known as Masaleh Mursala (public interest) to establish relations with the international community. The Islamic Fiqh (Jurisprudence) is taken from two kinds of sources; the prime sources including Qur'an, Sunnah, ijma' (consensus) and Qiyas (analogical reasoning), and secondary sources including the principle/ provision of Masaleh Mursala (public interest) among others. Thus, this principle is used by religious scholars and Fuquha' (Jurists) to issue Fatwa (legal opinion) for daily life practices (Abdulhamid, 2009: 12). Abu Zuhra identifies this principle as the interest in accordance with Maqasad Alsharia (objective), that is not stated by any original evident of either approval or denial i.e., by the prime sources. Hence, it is integrated in the common interests that are inculcated and entailed by Sharia generally. Moreover, the Jurist has not annulled nor approved it textually; rather, he classified it in the genus through many texts or general Maqasid (objectives) of Sharia."( Abdulhamid, 2009: 72). Regarding interest and its fulfillment for the individual, Ibn Qayyim explicates that "Sharia is based on governance and the interests of individuals here and in the hereafter. It is all about mercy and justice, and wisdom and interest, for if any of its issues takes the side of injustice instead of justice, opting away from mercy to its opposite, away from benefit to corruption and away from wisdom to frivolity, it is then not a part of Sharia, even if introduced by rational interpretation(Abdulhamid, 2009: 37)

The principle of 'public interest' is applicable to any domain that does not possess a referential text of Sharia to be considered as forbidden or permissible. Political actions like the international relations and agreements are all subject to this principle. Upon studying the legitimacy of any political action, decision makers and leadership determine where the common interest lays, and whether the implementation of said action brings about said interest. Their decision will be taken as a judgment to the action, keeping in mind that evaluation of the interest and proper interpretation to the different situation varies from time to time and from place to another depending on political variables at the time of decision making. People mostly differ in the evaluation of the interest, but ultimately all will abide by decision taken by the relevant authorities.

In the interviews, Hamas' leaders emphasized that they utilize independent reasoning in shaping their political actions outcome for the fulfillment of the interests of the Palestinian people, first, in a manner that is concordant with Islamic Sharia, and second, in a manner that does not relinquish any of the rights of the Palestinian people. In other words, contrary to what many statesmen and politicians believe in the rule saying ' the end justifies the mean,' Hamas leadership stressed on that all the means being used to establish and develop its foreign relations with other countries must be in accordance with Islamic Sharia. Moreover, these means must also contribute to accomplish the interests of the Palestinian people in all aspects, such as the liberation of their lands, as said by one of its leaders "The interest of our people and its fulfillment is one of the Sharia mandates, for wherever the interest can be fulfilled, so too can Allah's legislations can be fulfilled."( I. Alalmi, personal communication, June 11, 2014).

Hamas leadership believes that foreign relations with states and institutions is a contributing segment of the supportive strength which essentially aids in achieving the interests of the Palestinian people; "as political relations are a component of the comprehensive struggle against Israeli occupation, and though it may be aligned with the movement in terms of ideology and action, ultimately it is integrated with the actions of a greater armed struggle, and politically bolsters its achievements in the field."(Salih, et al. 2014: 533). Hamas believes in open relations with all states- except Israeldeveloping and initiating communications with them, regardless of their positions and political or religious leanings, as 
long as relinquishing the constants of the movement's position is not up for question, or the abandonment of defense of the Palestinian people's interests. Through research into the progression of Hamas movement's efforts, the researcher is of the opinion that the movement gives great priority to open relations with not only entire range of Arabic-Islamic sphere, but rather humanity in its entirety. Khalid Meshal asserts that "our issue is just, and this touches on and interacts with our regional and international surroundings; al-Quds and our Islamic and Christian holy sites are the concern for all of us; and all these have made Hamas to expand the options of its relations". (K. Meshal, personal communication, April 19, 2015).

In nutshell, it is clearly mooted in one of the Hamas internal documents, under the title of 'Political and Diplomatic Relations,' that Hamas emphasizes on establishing relations with all countries and international powers, on the basis of ensuring the significant role of the movement at the Palestinian, Arab and Islamic levels, and further affirming the legitimacy of the resistance, and the building of such relations on the basis of mutual interest".(Hurub, 1966: 212).

\subsubsection{Human Acquaintance: A Basis for Relations}

Hamas movement adopts the view that the bottom line of all relationships among nations and peoples is acquaintance building and cooperation, as revealed in the Qur'an, "O mankind, indeed We have created you from male and female and made you peoples and tribes that you may know one another. Indeed, the most noble of you in the sight of Allah is the most righteous of you. Indeed, Allah is Knowing and Acquainted."( Qur'an, (49:13), www.tanzil.net, last accessed on 26th Dec. 2015.). Allah (SWT) also states, "Allah does not forbid you from those who do not fight you because of religion and do not expel you from your homes- from being righteous toward them and acting justly toward them. Indeed, Allah loves those who act justly."( Qur'an, (60: 08), www.tanzil.net, last accessed on 26th Dec. 2015.). This is for the reason that Allah (SWT) has created humanity, and made them into diverse nations and peoples, of varying colors, languages, philosophies and beliefs. Thus, disagreement among peoples is natural; however, Allah (swt) mentions that these differences are in need of bridging through Ta'aruf (understanding), or the act of making acquaintances. In the words of Mohammad Sawalha, "Ta'aruf and cooperation among people is the essence of all human relations, not the war. Such Ta'aruf and cooperation must lead to benefit in terms of human service."( M. Sawalha, personal communication, March $23,2015)$. In the other mentioned verse, however, we find the basis for Hanas openness to establishment of relations with various nations and institutions, given that they have not wage a fight against us. The word Bir (righteous conduct) in the Arabic language merges all concepts of love and compassion, and has never been utilized in the Qur'an save for instances of relations with the parents. Its use in the context of justice and fairness in the formation of relations with those other than peaceful Muslims is a clear proof to Hamas to open relations with the international community. This worldview has enabled Hamas to accept the other -excluding the occupying force of Israel- and exercise attention to confidence building and cooperation with various state or non-state actors by means of all forms of political, social and economic relations. This, in turn, has led Hamas to formally adopted a policy of openness in developing relations with all, regardless of their political or ideological leanings of such actors. In the words of Khaled Meshal, Hamas leader of political bureau, "Hamas enjoys an open political mind policy with across the Arab and Muslim world and with the international community."( K. Meshal, personal communication, April 19, 2015). In this respect, Hamas believes that such an open mind policy per se is an opportunity to introduce itself to the world directly and without mediators then to carry the political stance and to explain the legitimate rights of the Palestinian people.

\subsection{Principles stemmed from practical experiences}

\subsubsection{Non-interference policy in states' internal affairs}

Head of Hamas foreign relations has clearly maintained that Hamas political leadership is totally committed to the principle of not interfering in the internal affairs of any state; "Hamas does not interfere in internal affairs of any state it shares relations with."( O. Hamdan, personal communication, Feb 15, 2015). This is further emphasized in Hamas internal documents and memorandum which the researcher was given an access to. The movement considers this as a critical policy that must be sustained, and which cannot be repealed in the establishment and development of foreign relations. Article 3 of the movement's political and diplomatic document under the title of "the relations with Arab and Muslim world" explicitly confirms two statements: "adherence to the policy of non-interference in the internal affairs of the states" and "Non-interference in state internal affairs."(Hurub, 1996). In this regard, Hamas has benefited significantly from the experiences of the Palestinian Liberation Organization, who interfered in internal affairs of few states. Such internal interference led to significant repercussions and negative implications affecting the Palestinian people residing in these states. One specific case includes the PLO's interference in the internal affairs of the Jordanian Kingdom in the late 
1960's and early 1970's which ultimately resulting in armed clashes, influencing all matters of civil life of the Kingdom. Yezid Sayigh notes that "the Jordanian police and courts lost their authority, then a Palestinian governing system stared to materialize to the limit that revolutionaries started to arrest, imprison, punish and interfere in matters of marriage and even property affairs; above and beyond all laws set down by the governing authority".(Sayigh, 2002: 364). This interference was one of the main reasons behind the military confrontation between the Jordanian army and PLO fighters, where hundreds on both sides were killed and injured, resulting in the expulsion of the PLO and its cadres from Jordan into Lebanon and Syria. The PLO repeated the same experience in Lebanon; Sayigh asserts that "the Palestinian Liberation Organization became more than a state inside the state of Lebanon."( Sayigh, 2002: 634). Fighters belonged to PLO participated in a civil war where hundreds of Palestinians were killed, and then led to great unrest, instigated hatred against Palestinians by many Lebanese.

Hamas has benefited greatly from this experience, and affirmed the non-interference policy in the internal affairs of states throughout its endeavours and efforts to establish foreign relations. The philosophy of Hamas in this respect is that the Palestinian people residing in other countries are "guests of these countries, and should be preoccupied with their own issues and the restoration of their usurped rights; therefore they must not get involved in internal affairs of the others." ( I. Alalmi, personal communication, June 11, 2014). Moreover, there is a keen awareness that any meddling with the security and stability of any state or threatening its security by means of interference in its internal affairs will make such states react aggressively and definitely it is impossible to support or build up any relation with ever who threatens its security and peace. Osama Hamdan notes in this regard, "Hamas by no means carries any security threat to any country; and this has served positively the movement's political relations to a great extent." $\mathrm{O}$. Hamdan, personal communication, Feb 15, 2015). By means of adhering to this principle in establishing and developing political relations with the countries, and by focusing only on the championing of the Palestinian issue, Hamas has been able to expand its relations to various parties and civil society groups in such countries. In addition to relations with the existing governments and statesmen, Hamas has been able to establish relations with opposition parties in the same countries without any objection from the hosting government. This is found quite clearly in a number of countries that share relations with the movement. In Lebanon for instance, Hamas movement has established open relations through its representatives and leadership, with the Lebanese government, and the entire range of varying political parties, as well as civil society. The same can be said of Sudan, the Kingdom of Jordan, Yemen, Malaysia and Egypt. Osmah Hamdan reiterates significantly that, "Hamas movement's relations with others are associated with the Palestinian issue, and what these parties provide to the issue. From one angle, we do not interfere with internal affairs, and from another aspect, we carry the concerns of this issue to everyone. We have found often, that our issue is the point of convergence between governments and opposition parties."( O. Hamdan, personal communication, Feb 15, 2015). Hamas has, moreover, made relations with the opposition parties and civil society in public and in transparent manners, avoiding any secret relations i.e., Hamas has made those relations through coordination and full knowledge of the hosting governments. Hamdan also notes that "the movement's representatives communicate with all parties and forces publically and with the government's knowledge, as Hamas conceals nothing in these relations which could possibly elicit fear or concern of people as well as the governments."( 0 . Hamdan, personal communication, Feb 15, 2015). The movement consistently announces its readiness to interact with all forces and parties, regardless of their political views or ideologies: Islamic, nationalistic, leftist, liberal etc. This is to bring about a unity of efforts in championing and advancing the Palestinian people's issue.

\subsubsection{The Independence of the decision}

Hamas takes its own decisions through the leadership of its organizational and administrative institutions. Hamas leadership is distributed across four regions or areas where the movement's members are to be found. These are as follows: Gaza strip, West Bank, areas outside Palestine or the Diaspora, and Zionist prisons. Each of these four regions selects internal leadership which administrates its affairs. This is done through free elections held by secret ballot. Following elections, each region selects their representatives for the movement's (Majlis al-shura Al-aam)) (General Consultative Council). Then this council elects the leader of the political bureau and his vice.

In the first meeting of the General Cconsultative Council an election is held to determine the leader of the political bureau (the movement's de facto leader), following which the council ratifies the members of the political bureau, drawn from the three regions through understandings with the political bureau's leader.

Hamas adopts the view that the decisions made in the General Cconsultative Council are binding across the range of its organizational and leadership institutions. It affirms this in its rules of procedures, stating that Shura (consultative) decree is binding and is the adopted basis for decision-making."(Salih, et al. 2014: 533). This was further emphasized by Shaikh Ahmed Yassin, the founder of Hamas, in one his letters, "it is unacceptable for an individual or a group of 
individuals to adopt isolated decisions on the future of our mission (our movement), and any decision adopted by the majority will be binding for all."(Hurub, 1996: 64). Hamas adherence to this mechanism in taking decisions essentially distances the movement from being dominated or controlled by any ally or friends. Furthermore, it grants virtual immunity to the movement from any attempt at intimidation or blackmail. In one of his issued press releases, Khalid Meshal directed a speech to the United States of America and the European Union, stating that " the attempts you undertake and efforts you exert to have us abandon our principles and struggle will go to waste; Hamas is immune to bribery, intimidation and blackmail."( Zaytuna Institute, 2006: 410).

Hamas has taken cares to ensure its independence in decision-making, by emphasizing that it belongs to both the Arab and Islamic Ummahs (nations), while not allowing any of its allies or friends any room for interference in its decisions. In this respect, it is conducive to cite a number of examples;

When Hamas established itself in Jordan, it vehemently opposed the Oslo accords with the occupying state of Israel by all means, and exerted all efforts to halt and undermine the accords in spite of the fact that Jordan was in favor of the process, rather that the King of Jordan Hussein Ibn Talal himself had signed the Wadi 'Arabah accord of 1994 with the occupying state of Israel. The presence of Hamas in a country that had supported and participated in furthering the Oslo Accord did not affect its decisions in opposing the accord. Moreover, the political and financial assistance the movement received from Iran and Syria did not affect its adoption of a number of decisions to please those countries. For instance, Hamas had participated in the elections of the Palestinian Legislative Council (PLC) in West Bank's and Gaza Strip in 2006 in spite of Iran's opposition to such participation. Syria held negotiations with the occupying state of Israel and Hamas had consistently declared its opposition to any negotiations or agreements. Khalid Meshal plainly states that "Hamas decision is stemmed from the Palestinian reality, and is not a result of any affiliation with any others. This is a known truth to all, with testament of the reality and practice. There is no exchange price to be set for a safe haven; if we had done so, our current positions would have been other than that which you see now; our presence in this or that country is a part of our right to our Ummah (nation), and it came out of Palestinians in diaspora to live away from their homeland."(Salih, et al. 2014: 364).

It is important to highlight that despite the fact that Hamas roots tracing to the Muslim Brotherhood and the excellent and strong relations with each other, Hamas has not left its decisions subordinated to the Brotherhood leadership. It further, Hamas refused the Brotherhood leadership request or decision to not establish relations with states hostile to the Brotherhood. Sami Khater notes that "the Muslim Brotherhood had opposed forming relations with the Syrian and Libyan regimes, only to-after discussions-come to terms with and accept the position of the movement".( $\mathrm{S}$. Khater, personal communication, March 25, 2015). This was because a conviction had taken root among all actorsincluding the Muslim Brotherhood- that the Palestinian issue is a shared issue, and it unites all authorities, and inclinations regardless of their different political or intellectual perspectives; and the Palestinian cause requires the efforts of all. In this respect, it would require open door policy to all, as emphasized by Khalid Meshal, "since the existence of Hamas, no restrictions have been imposed on the movement by any one. The ultimate references of the movement are its political and executive leaders, and the Shura institution; it is not bound by any policy or decision or any other references from any side. Rather, it is a caretaker to the concerns and spirit of the Ummah, but exerts itself with what it deems appropriate and necessary within the Palestinian issue."( K. Meshal, personal communication, April 19, 2015).

Financial support is potentially one of the most dangerous matters that affect the internal decision-making of political movements and national liberation movements. Alert to this, Hamas leadership have taken steps to safeguard its leadership from a number of potentially embarrassing situations, by adopting a policy of refusing any conditional financial support. This position is explained to all states which Hamas enjoys relations with, as stated by Khalid Meshal in a press conference, "Hamas welcomes all unconditional financial support from Arab or Muslim countries, and refuses that the Palestinian resistance be exploited politically by any side."( Zaytuna Institute, 2006: 373). This stance is echoed by the movement leadership and its representatives in all countries.

In the election program of the slate of 'Change and Reform', which used to represent Hamas during the election for the Palestinian legislative council of 2006, the following was declared, "Refusal of grants conditional upon relinquishments of national constants, and strive to seek more honest alternatives".(Salih, et al. 2014: 584). Hamas has also established a general policy for its leadership and representatives in a strict policy for dealing with personal gifts from states, governments and institutions to keep them immune from personal pressure and embarrassment and distance them from personal or direct influence, as found in one such policy, "where a gift's value exceeds $\$ 100$, it shall be transferred to the movement's central fund, and the donors shall be notified of this policy."( S. Khater, personal communication, March 25, 2015). 


\subsubsection{Non-Allied policy}

Observer to the present situation of Arab and Islamic states finds a number of contradictions and conflicts among these states. From time to time, alliances emerge and manifest underlying tensions and over a specific point. An example of this is the coalition of Arab states that supported the Iraqi regime in the Iraq-Iran Gulf war in the 1980's. Hamas believe strongly that Palestine is an issue shared by all Arabs and Muslims primarily, and is in need of more efforts to confront the Zionist settling campaign. By examining the dangers inherent in these conflicts and contentions among Arab and Islamic states, Hamas has strategized for itself a number of policies and measures to protect itself and its policy not to slip into the arena of conflicting axes in the region. These policies are as follows;

a. Hamas does not perceive alliances as inherently negative, as the presence of an alliance aids the Palestinian people's resistance, and supports it along the path of reclaiming the rights in ending the occupation; therefore, it is a welcome presence and that Hamas has to be integrated into such an alliance, as Khaled Meshal states, "there are commendable and not-commendable alliances. We do not commend a coalition based for instance on sectarian divides, or by raising the elements of isolation and internal alignment- on the level of Ummah (nation) and homeland-and only serves to divide but not to unite. Rather we commend to unite people on the basis of common cause and in support of the Palestinian people." ( K. Meshal, personal communication, April 19, 2015). Mahmoud Sawalha also asserts that "with the existence of any alliance that stands with the resistance of the Palestinian people, it is mandatory for Hamas to be a part of said alliance. ( M. Sawalha, personal communication, March 23, 2015).Another policy includes the non-interference between conflicting states, adoption of neutrality with regards to both parties, and not altering the stands and policies of the movement for the interest of one party over another. This is primarily so that the Palestinian issue remains free from polarization and instead unites all with no exception, while avoiding the making enemies of any nation. Mousa Abu Marzook states, "in our official meetings with authorities from conflicting states, we avoid absolutely speaking about their rival or opponent in such meetings."( M. Abu Marzook, personal communication, March 28, 2015).

b. Hamas leadership close adherence to this policy in spite of the difficulty and challenges this policy poses, has granted it legitimacy between conflicting parties. Moreover, this stand has granted it a dynamic flexibility and capability to balance between conflicting parties with ease. Cases in point include functioning balances between opposing parties such as Iran and Iraq, Iran and Saudi Arabia, Syria and Jordan, and Saudi Arabia and Egypt.

c. Hamas leadership is of the view that supporting the resistance and safeguarding of Palestinian rights should be the foundation of its foreign relations with state actors. Moreover, its adherence to the right of the Palestinian people to self-determination and resistance and refusal of 'solutions' and 'peace accords' are not specifically directed against any Arab party. Rather, it is an expression of the conviction and principles the movement holds to. Khalid Meshal points out that "we do not contract the enmity of anyone in our Ummah, and call upon all states of the Ummah to align together at the rational square of resistance at the time of exposure to aggression, and in our refusal of the American-Zionist vision of issue settlement, we do not consider this as opposition to any Palestinian or Arab actors; but rather confronting to the Zionist foe."(Meshal,K: 55) Consistency and continuity of resistance in spite of Hamas leadership geographical mobility from Jordan, to Qatar, to Syria, followed by a return to Qatar, has established a model of steadfastness to carrying out the resistance against the occupation, and furthermore finding a shared vision with friends and allies who support this resistance. Saleh Muhsin emphasizes that "Hamas has not shifted from alliance to alliance; rather Palestine and the Palestinian resistance is the original and the center of the resistance."(Salih, et al. 2014: 474).Openness to all parties and allies, as this is a rational behavior for a movement that seeks to maximize the number of its allies, contributors and supporters. Therefore, the movement exerts efforts for the sake of finding balance in its political relations with all Arab and Islamic states, hence Hamas "takes care to establish and develop relations with disputing states simultaneously".(M.Abu Marzook, personal communication, March28, 2015). This is to entrench and further reinforce its policy of openness and balance in relations. For instance, at the same time as the opening of the movement's representative office in Iran, the leadership visits to Iraq and Saudi Arabia continued and not interrupted. Khalid Meshal notes here that "at the time when the movement was in allies with Syria, Iran and Hezbollah (Axis of resistance), the movement also had relations with the Arab moderate axis, as it sought to emphasize on the policy of openness to all."( K. Meshal, personal communication, April 19, 2015).

HAMAS movement has never allowed political, ideological or partisan disagreements to stand in the way of 
openness, or the acceptance of a party's support and contributions in any manner possible. Rather, the movement sees that the Palestinian people are in need of support by the entirety of the Ummah in every form; be it political, intellectual, sectarian, or religious. This is precisely what Khalid Meshal affirms, "we do not only need the support of Islamist, but rather, we are in need of an entire Ummah with all its streams of thought and components; Islamists, nationalists, liberals, leftist etc. It is essential to disassociate with any division based on sect, ethnicity or religion."(Salih, et al. 2014: 478).

\section{Restrict of Military Action to within Palestine}

Hamas has launched and limited the theatre of military confrontation with the Zionist occupation within Palestine only. It has never conducted any military operations against Israeli targets outside of Palestine. In this manner, it has adhered to a general policy drafted by the leadership in the first years of its establishment. A memorandum entitled, "Policies of the Interim period" states that "the movement considers Palestine to be the theatre for military confrontation with the Zionist enemy, and takes care to not prevent the spill-over of the battle outside Palestinian occupied lands. However, it does not disregard any actions of Jihad (fighting) against the Zionist occupation launched by any party outside Palestine."(Hurub, 1996: 172). The same is strongly emphasized by the Hamas political bureau- the responsible body in the movement for forming and developing foreign relations with state-actors, in an issued memorandum entitled, "Foreign Relations and Diplomacy", on "to not expand the theatre of conflict with the enemy outside the confines of the occupied land.(Hurub, 1996: 212).

As mentioned earlier, Hamas has benefited greatly from the study of the experiences of PLO factions who carried out a number of military operations outside of Palestine. For example, they targeted a number of Israeli targets outside occupied Palestine, including the targeting of the Israeli Olympic team in the Summer Olympics held in Munich, Germany, in 1972, leading to the killing of 11 Israeli athletes. In response, the Israeli occupying force bombed Palestinian Commando bases in Jordan, and Lebanon; and also bombed and destroyed vital infrastructures in these countries. Sayigh states that "the Israeli Air Force carried out bombing raids on Commando bases. The Aqaba port was also targeted by heavy bombing, after the city of Eilat was exposed to rocket-fire in April/May of 1969".(Sayigh, 2002: 307). Moreover, the Israeli army also invaded Lebanese territories, reached Beirut, and destroyed significant areas of its infrastructure in the year of 1982, claiming the campaign to end the attacks of Palestinian commandos.

Following the study and follow-up of these experiences, the crystallized view held by Hamas leadership was that "the experiences of the PLO factions in expanding the field of military engagement and Jihadi missions against the Zionist enemy, affirms the correct decision to adopt the policy of confining the military activities within Palestine".( 0 . Hamdan, personal communication, Feb 15, 2015). Hamas leadership views this policy as not to disperse the military action and is due to a number of considerations, primarily to establish constructive environments for forming relations with state-actors, as attacking Israeli targets outside of Palestine will undermine security and stability in the place of action, which would lead to tension in relations between such countries and the movement. Khalid Meshal notes in this respect that "our avoidance of targeting the enemy and its interests outside of Palestine is not based on inability, but rather to prevent the enmity of others. Moreover, we support peace and security in relations among peoples and nations."( K. Meshal, personal communication, April 19, 2015). This is based on a premise of simple interest, where a state that feels an actor threatens its security and stability will not form relations with the said actor. Osama Hamdan also reiterates this perspective, "Hamas movement has emerged and surpassed the circle of being a posed security threat to any state; for the reason that it focuses on the struggle with the enemy inside Palestine. This served us in developing political relations and opening numerous doors in our relations with states."( O. Hamdan, personal communication, Feb 15, 2015).

The occupying state has nonetheless carried out a number of assassination operations against Hamas political leaders outside of Palestine, as with the assassination of Izz El-Deen Sheikh Khalil in Damascus, 2004 or the assassination of Mahmoud al-Mabhouh in Dubai, 2010, and even a previous assassination attempt against HAMAS Political Bureau leader Khalid Meshal in Jordon. However, HAMAS did not retaliate against these operations outside Palestine, and kept the military action within occupied Palestine. Osamah Hamdan clarifies that "for this reason, a number of states have realized that it is dealing with a serious, focused movement that clearly distinguishes its enemy and theatre of combat. Moreover, they have realized that it is not possible for the movement to be dragged into external conflict aside from their own primary struggle inside Palestine, and this has lead to the development of relations with the movement." (O. Hamdan, personal communication, Feb 15, 2015).

\section{Conclusion}

Hamas adoption and adherence to the principles stemmed from the Islamic Sharia and got from the thorough study of the 
experiences of other liberation factions and movements, mainly the Palestinian ones, have undoubtedly contributed in the development of its foreign relations with various countries in the world. Hamas is consistently ready and willing to open relations with all, regardless of their political or religious backgrounds, who believe in justice and support its efforts in achieving the Palestinian people rights to live in their lands peacefully like other nations in the world. Another study is recommended to examine the positions of the countries that yet have not established or tried to open any kind of relations with Hamas.

\section{References}

Creswell, J. (2013). Research design: Qualitative, quatntitative, and mixed methods approaches (4th Ed). Sage: London Holy Qur'an.

Hurüb, Khalid. (1996). Hamas̄: al-fikr wa-al-mumarasah al-siyas̄ìzah. Bayrü: Mu’assasat al-Dirāsat al-Filiștinììah.

Khalid Meshal. Jawla fế al-Fikr al-SiyÉsi IÊ xarakat ×amÉs. HAMAS Islamic Resistance Media and Publications Bureau).

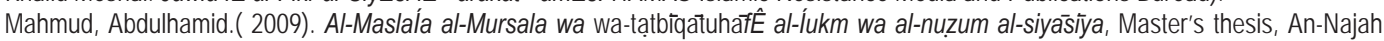
National University.

Șalịh, Muḥsin, et al (editors). (2014). Harakat al-Muqāwamah al-Islāmiyah Hamas̄: dirāsat fíal-fikr wa-al-tajrubah.

Sayigh, Yezid.(2002). Armed Struggle and the Search for State: The Palestinian National Movement, 1949-1993. New York: Oxford University Press.

Zaytuna Institute. (2006). Khalid Meshal: Articles, Interviews and Stands 1999-2006. Beirut.

Merriam, S, (2009), Qualitative research: A guide to design and implementation. Jossy-Bass.

\section{Personal Interviews}

Imad Alalmi, member of HAMAS Movement Political Bureau. Istanbul, Turkey. 2014/6/11. 19:00.

Khalid Meshal, Leader of HAMAS Movement Political Bureau. . Doha, Qatar 2015/4/19. 22:00.

Mahmoud Sawalha, responsible for Movement's international relations. Doha, Qatar. 23/3/2015. 10:00.

Mousa Abu Marzook, Deputy-chief of HAMAS Movement Political Bureau, Head of Political Circle. . Doha, Qatar 2015/3/28. 11:00.

Osama Hamdan, Formerly responsible for HAMAS Foreign Relations. Doha, Qatar 2015/2/15. 11:30.

Sami Khater, member of HAMAS Movement Political Bureau. Doha, Qatar 2015/3/25. 22:00. 